\title{
PENGARUH PENGGUNAAN PS BALL SEBAGAI PENGGANTI PASIR TERHADAP KUAT TEKAN BETON
}

\author{
Ronald Simatupang, Naning Diyah Ulfaturosida \\ Jurusan Teknik Sipil, Fakultas Teknik, Universitas Kristen Maranatha, Bandung
}

\begin{abstract}
Development in the current structure is progressing very rapidly which took place in various fields. Concrete is one option as a structural material in building construction. But with increasing climate change needs an innovation in the world of construction to be able to create a concrete constituent materials friendly to the environment. One way to use the waste products of steel called a PS Ball. The purpose of this research is to knowing the effect of using PS Ball as a replacement of sand in to compressive strength. Result obtained from research performed is that the PS Ball can use as the replacement of sand in the mix concrete. The increase in compression strength of concrete when PS Ball as sand replacement is 1,16 from normal concrete.
\end{abstract}

Keyword: PS Ball, Compressive Strength, concrete, sand replacement.

\section{PENDAHULUAN}

Berbagai penelitian dan percobaan dibidang beton dilakukan sebagai upaya untuk meningkatkan kualitas beton. Teknologi bahan dan teknik pelaksanaan yang diperoleh dari hasil penelitian dan percobaan tersebut dimaksudkan untuk menjawab tuntutan yang semakin tinggi terhadap pemakaian beton serta mengatasi masalah-masalah yang sering terjadi pada saat pengerjaan di lapangan. Dalam pembangunan gedung-gedung bertingkat tinggi dan bangunan lainnya sangat dibutuhkan beton dengan kekuatan yang tinggi, beton mutu tinggi adalah pilihan yang paling tepat.

Peningkatan mutu beton dapat dilakukan dengan memberikan bahan pengganti. Dari beberapa bahan pengganti salah satunya adalah PS Ball, diharapkan dengan mengganti pasir beton dengan PS Ball dapat meningkatkan kuat tekan beton.

PS Ball sangat unggul dibanding pasir dalam hal kekuatan tekan, kekerasan dan anti-weathering. Strukturnya sangat kuat, tahan cuaca dan tidak mudah aus dengan bentuk bulat mengkilap. PS Ball cocok untuk berbagai penerapan berkat sifat fisik dan kimianya. Yang paling penting adalah fakta bahwa PS Ball tidak berbahaya dan ramah lingkungan yang dihasilkan oleh teknologi yang bebas pengaruh negatif terhadap lingkungan. Tujuan utama dari penelitian ini adalah Untuk mengetahui pengaruh penggunaan PS Ball sebagai pengganti pasir terhadap kuat tekan beton. Persentase PS Ball yang digunakan sebagai pengganti pasir yaitu 5\% - 50\% dengan kenaikan setiap 5\%. Kuat tekan beton $\left(f c^{\prime}\right)$ dalam penelitian ini sebesar $25 \mathrm{MPa}$. 


\section{TEORI}

\section{Beton}

Beton merupakan salah satu bahan konstruksi yang telah umum digunakan untuk bangunan gedung, jembatan, jalan dan lain sebagainya. Beton merupakan suatu kesatuan yang homogen. Beton didapatkan dengan cara mencampur agregat halus (pasir), agregat kasar (kerikil), air, dan semen. Dan bisa dengan bahan tambahan yang bersifat kimiawi ataupun fisikal pada perbandingan tertentu, sampai menjadi satu kesatuan yang homogen. Campuran tersebut akan mengeras seperti batuan. Pengerasan terjadi karena peristiwa reaksi kimia antara semen dengan air.

Membuat beton sebenarnya tidaklah sederhana hanya sekedar mencampurkan bahan-bahan dasarnya untuk membentuk campuran yang plastis sebagaimana sering terlihat pada pembuatan bangunan sederhana. Tetapi jika ingin membuat beton yang baik, dalam arti memenuhi persyaratan yang telah ditentukan karena tuntutan yang lebih tinggi, maka harus diperhitungkan dengan seksama cara-cara memperoleh adukan beton segar yang baik dan menghasilkan beton keras yang baik pula. Beton segar yang baik ialah beton segar yang dapat diaduk, dapat diangkut, dapat dituang, dan dapat dipadatkan.

\section{Sifat-Sifat Umum Beton}

Untuk keperluan perancangan dan pelaksanaan struktur beton, maka pengetahuan tentang sifat-sifat adukan beton maupun sifat-sifat beton setelah mengeras perlu diketahui. Sifat-sifat tersebut antara lain:

\section{Tahan Lama (Durability)}

Merupakan kemampuan beton bertahan seperti kondisi yang direncanakan tanpa terjadi korosi dalam jangka waktu yang direncanakan. Dalam hal ini perlu pembatasan nilai faktor air semen maksimum maupun pembatasan jumlah semen minimum yang digunakan sesuai dengan kondisi lingkungan. Sifat tahan lama pada beton dapat dibedakan dalam beberapa hal, antara lain sebagai berikut:

a. Tahan Terhadap Pengaruh Cuaca

Pengaruh cuaca yang dimaksud adalah pengaruh yang berupa hujan dan pembekuan pada musim dingin, serta pengembangan dan penyusutan yang diakibatkan oleh basah dan kering silih berganti.

b. Tahan Terhadap Pengaruh Zat Kimia

Daya perusak kimiawi oleh bahan-bahan seperti air laut, rawa-rawa dan air limbah, zat-zat kimia hasil industri dan air limbahnya, buangan air kotor kota 
yang berisi kotoran manusia, susu, gula, dan sebagainya perlu diperhatikan terhadap keawetan beton.

c. Tahan Terhadap Erosi

Beton dapat mengalami kikisan yang diakibatkan oleh adanya orang yang berjalan kaki dan lalu lintas diatasnya, gerakan ombak laut, atau oleh partikelpartikel yang terbawa oleh angin dan air.

\section{Kuat Tekan}

Kuat tekan beton ditentukan berdasarkan pembebanan pada silinder beton dengan diameter $150 \mathrm{~mm}$ dan tinggi $300 \mathrm{~mm}$. Rumus untuk menghitung kuat tekan beton yaitu :

$f_{c}^{\prime}=P / A$

Dimana:

$f_{c}{ }^{\prime}=$ Kuat tekan $(\mathrm{MPa})$

$P=$ Beban tekan maksimum yang dapat ditahan $(\mathrm{N})$

$A \quad=$ Luas penampang silinder (mm)

3. Kuat Tarik

Kuat tarik beton jauh lebih kecil dari pada kuat tekannya, yaitu sekitar $10 \%$ sampai $15 \%$ dari kuat tekannya. Kuat tarik beton merupakan sifat yang penting untuk memprediksi retak dan defleksi balok. Rumus untuk menghitung kuat tarik beton yaitu:

$f_{c t}=2 P / \pi L D s$

Dimana:

$f_{c t}=$ Kuat tarik benda uji $(\mathrm{MPa})$

$P=$ Beban tekan maksimum yang dapat ditahan (N)

$L=$ Panjang benda uji (mm)

$D s=$ diameter benda uji (mm)

4 Modulus Elastisitas

Modulus elastisitas merupakan hubungan linier antara tegangan dan regangan untuk suatu batang yang mengalami tarik atau tekan. Semakin besar harga modulus ini maka semakin kecil regangan elastis yang terjadi pada suatu tingkat pembebanan tertentu, atau dapat dikatakan material tersebut semakin kaku.

Modulus elastisitas dapat dihitung dengan persamaan:

$E=\sigma / \varepsilon$

Dimana:

$\sigma=$ Tegangan aksial searah sumbu benda uji (MPa) 
$\varepsilon=$ Regangan aksial

$E=$ Modulus elastisitas beton $(\mathrm{MPa})$

Modulus elastisitas suatu material ditentukan oleh energi ikat antar atom - atom, sehingga besarnya nilai modulus ini tidak dapat dirubah oleh suatu proses tanpa merubah struktur bahan. Modulus elastisitas adalah kemiringan kurva tegangan regangan di dalam daerah elastis linier pada sekitar $40 \%$ beban puncak. (Ultimate load) (Gere dan Timoshenko, 1997).

5. Rangkak (creep)

Merupakan salah satu sifat dimana beton mengalami deformasi terus menerus menurut waktu dibawah beban yang dipikul.

\section{Susut (Shrinkage)}

Merupakan perubahan volume yang tidak berhubungan dengan pembebanan.

7. Kemampuan dikerjakan (Workability)

Workability adalah bahwa bahan-bahan beton setelah diaduk bersama, menghasilkan adukan yang bersifat sedemikian rupa sehingga adukan mudah diangkut, dituang atau dicetak, dan dipadatkan menurut tujuan pekerjaannya tanpa terjadinya perubahan yang menimbulkan kesukaran atau penurunan mutu. Sifat mampu dikerjakan (workability) dari beton sangat terganggu pada sifat bahan, perbandingan campuran, dan cara pengadukan serta jumlah air. Dengan kata lain, sifat mudah dikerjakan suatu adukan beton dipengaruhi oleh beberapa faktor yaitu:

a. Konsistensi normal PC.

b. Mobalitas, setelah aliran dimulai (sebaliknya adalah sifat kekasaran atau perlawanan terhadap gerak).

c. Kohesi atau perlawanan terhadap pemisahan bahan-bahan.

d. Sifat saling lekat (ada hubungannya dengan kohesi), berarti bahan penyusunannya tidak akan terpisah-pisah sehingga memudahkan pengerjaanpengerjaan yang perlu dilakukan.

Perbandingan bahan-bahan ataupun sifat bahan-bahan itu secara bersama-sama mempengaruhi sifat dapat dikerjakan beton segar. Unsur-unsur yang mempengaruhi sifat mudah dikerjakan antara lain sebagai berikut:

a. Banyaknya air yang dipakai dalam campuran aduk beton. Makin banyak air yang digunakan, makin mudah beton itu dikerjakan. 
b. Penambahan semen ke dalam adukan beton. Hal ini juga menambah kemudahan dikerjakan pada beton, karena biasanya penambahan semen diikuti dengan penambahan air untuk memperoleh harga faktor air semen tetap.

c. Gradasi campuran agregat kasar dan agregat halus. Jika campuran pasir dan kerikil mengikuti gradasi yang telah disarankan oleh peraturan sesuai dengan SNI 03-28342000, adukan beton akan mudah dikerjakan. Pemakaian butir-butir agregat yang bulat akan mempermudah cara pengerjaan beton. Pemakaian butir maksimum agregat kasar, akan berpengaruh terhadap kemudahan dikerjakan pada aduk beton.

d. Cara pemadatan beton dan jenis alat yang digunakan. Jika pemadatan beton dilakukan dengan menggunakan alat mesin getar, maka tingkat kelecekannya pun akan berbeda-beda jika dibandingkan dengan menggunakan alat yang lain.

\section{PS BALL}

Slag EAF merupakan produk samping dengan volume besar yang terbentuk dalam proses pembuatan baja (15\% sampai $20 \%$ dari kapasitas baja cair) dimana masih mengandung sisa-sisa metal. Penanganan slag ini sebelumnya sulit dan metodenya tidak efisien.

Teknologi slag atomizing (Slag Atomizing Technology: SAT) merupakan sistem baru untuk membentuk slag cair menjadi butiran kecil (atomize) dari Electric Arc Furnace (EAF) dengan efisiensi tinggi. Material hasil dari proses $S A T$ berbentuk bola dengan diameter dan ukuran yang berbeda-beda, dan disebut PS (Precious Slag) ball.

SAT plant pertama beroperasi pada 1997 di Korea, sejak itu total kapasitas terpasang telah meningkat menjadi 1,12 juta ton. Kapasitas yang sedang dibangun dan diproyeksikan akan direalisasikan pada 2009 di Korea Selatan, Afrika Selatan, Malaysia, Thailand, Taiwan, Indonesia, Iran, Vietnam dan Amerika Serikat berjumlah 3,4 juta ton. Tanggal 1 Desember 2008 SAT Plant di PT Purna Baja Harsco (di dalam kawasan pabrik PT Krakatau Steel) mulai beroperasi, dengan kapasitas 5.000 ton per bulan.

$S A T$ merupakan proses merubah slag cair $\left(1500^{\circ} \mathrm{C}-1550^{\circ} \mathrm{C}\right)$ menjadi bola-bola kecil dengan diameter berkisar antara 0,1 mm sampai 4,5 mm. Prosesnya berupa sistem hembusan angin berkecepatan tinggi dengan katalis dan air pada aliran slag cair yang ditumpahkan melalui tundish menuju slag pitt. Dengan bantuan air, aliran udara berkecepatan tinggi menghasilkan pertukaran panas yang cepat yang merubah aliran slag menjadi bola-bola (PS Ball) dengan permukaan yang mengkilap. Struktur PS Ball dipisahkan berdasarkan ukurannya dalam suatu mesin pengayak. PS Ball memiliki 4 ukuran dari butir kasar sampai dengan butir halus : 

1. 4 - $10 \mathrm{MESH}$
2. $10-20 \mathrm{MESH}$
3. 20 - $40 \mathrm{MESH}$
4. $40-200 \mathrm{MESH}$

PS Ball produk ramah lingkungan hasil olahan limbah B3 yang dapat digunakan untuk material blasting sebagai pengganti pasir kuarsa. Pada Gambar 1 dapat dilihat proses produksi dari PS Ball.

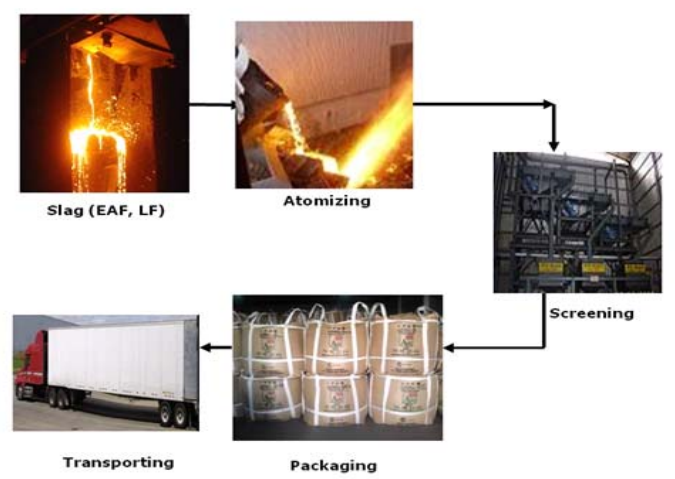

\section{Gambar 1. Proses Produksi PS Ball. \\ (sumber: P.T. Purna Baja Harsco)}

Dalam proses $S A T$, slag cair didinginkan dengan cepat oleh udara dan air berkecepatan tinggi. Berbagai unsur tidak stabil membentuk $\mathrm{CaO}-\mathrm{Fe}_{2} \mathrm{O}_{3}, \mathrm{SiO}_{2}-$ $\mathrm{Fe}_{2} \mathrm{O}_{3}$ dan $\mathrm{Mg}-\mathrm{Fe}_{2} \mathrm{O}_{3}$. Tidak ada $\mathrm{CaO}$ bebas di dalam produk, dan permukaan akan mengkilap dengan adanya struktur spinel. Struktur spinel merupakan bentuk kombinasi dari $\mathrm{CaO}-\mathrm{Fe}_{2} \mathrm{O}_{3}, \mathrm{CaO}-\mathrm{SiO}_{2}$. Pada Gambar 2 dapat dilihat bentuk butiran dari PS Ball.
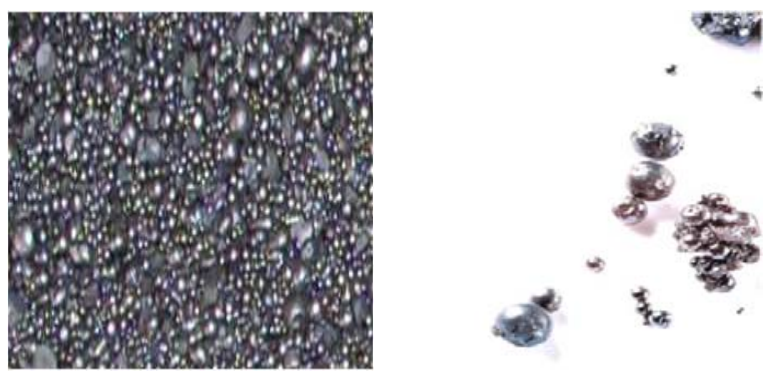

Gambar 2. Karakteristik PS Ball.

(sumber: P.T. Purna Baja Harsco)

Pengaruh Penggunaan PS Ball Sebagai Pengganti Pasir Terhadap Kuat Tekan Beton (Ronald Simatupang, Naning Diyah Ulfaturosida) 
PS Ball adalah singkatan dari Precious Slag Ball, material baru yang dihasilkan dari slag EAF. PS Ball memiliki permukaan mengkilap dengan struktur spinel yang stabil. PS Ball berbentuk bulat dengan diameter antara 0,1 sampai 4,5 mm, material dengan tidak ada kapur bebas.

PS Ball cocok untuk berbagai penerapan, berkat sifat fisik dan kimianya. Yang paling penting adalah fakta bahwa PS Ball tidak berbahaya dan ramah lingkungan yang dihasilkan oleh teknologi yang bebas pengaruh negatif terhadap lingkungan. Struktur kimiawi dari PS Ball dapat dilihat pada Gambar 3:

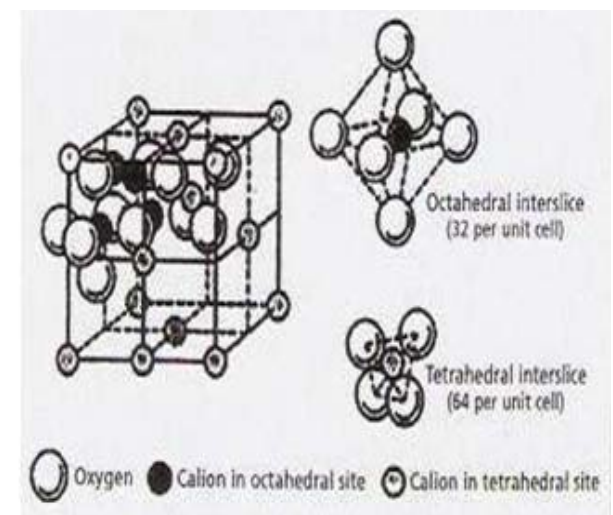

Gambar 3. Struktur Spinel PS Ball. (sumber: P.T. Purna Baja Harsco)

Struktur spinel merupakan ciri utama material ini, struktur fisik dan kima yang stabil yang menghilangkan alasan polusi. Nilai persentase kandungan kimiawi dari PS Ball dapat dilihat pada Tabel 1. 
Tabel 1. Persentase Kandungan Kimiawi PS Ball.

\begin{tabular}{|l|l|}
\hline \multicolumn{1}{|c|}{ Kandungan Kimia } & \multicolumn{1}{|c|}{ Nilai } \\
\hline $\mathrm{T}-\mathrm{Fe}$ & $20,83 \%$ \\
$\mathrm{M}-\mathrm{Fe}$ & $<0,10 \%$ \\
$\mathrm{FeO}$ & $3,35 \%$ \\
$\mathrm{Fe}_{2} \mathrm{O}_{3}$ & $26,06 \%$ \\
$\mathrm{SiO}_{2}$ & $12,69 \%$ \\
$\mathrm{CaO}$ & $40,30 \%$ \\
$\mathrm{Al}_{2} \mathrm{O}_{3}$ & $2,20 \%$ \\
$\mathrm{MgO}$ & $7,95 \%$ \\
$\mathrm{Na}_{2} \mathrm{O}$ & $<0,10 \%$ \\
\hline Kekerasan & $739,8 \mathrm{HVC}$ \\
Diameter & $0,1-4,5 \mathrm{~mm}$ \\
Massa Jenis & $2,3 \mathrm{~kg} / \mathrm{l}$ \\
Permeabilitas Air & $530 \mathrm{~cm} / \mathrm{s}$ \\
Kekuatan Tekan & $323 \mathrm{~kg} / \mathrm{cm}^{3}$ \\
\hline
\end{tabular}

(sumber: P.T. Purna Baja Harsco)

\section{Karakteristik Penggunaan PS Ball}

Karakteristik dari material PS Ball dibandingkan dengan material lain yang ada dapat diihat pada Tabel 2.

Tabel 2. Karakteristik Material PS Ball.

\begin{tabular}{|c|c|c|c|c|c|}
\hline Classification & PS Ball & Sand & Garnet & Glass Bead & Stell Ball \\
\hline $\begin{array}{c}\text { Actual Specific } \\
\text { Gravity }\end{array}$ & 3,45 & 2,62 & 4,2 & 2,6 & 7,2 \\
\hline Mohs Hardness & 7,5 & 5,5 & 7,5 & 5 & 8,5 \\
\hline $\begin{array}{c}\text { Rockwell } \\
\text { Hardness (HRC) }\end{array}$ & 43 & 30 & 40 & 28 & 50 \\
\hline $\begin{array}{c}\text { Brightness } \\
\text { (quality grade) }\end{array}$ & Very good & Normal & Good & Normal & Very good \\
\hline Reusability & $1-3$ times & One time & 1-3 times & One time & 5-7 times \\
\hline
\end{tabular}

(sumber: P.T. Purna Baja Harsco) 


\section{Keuntungan Penggunaan PS Ball}

PS Ball sangat unggul dibanding pasir dalam hal kekuatan tekan, kekerasan, dan anti-weathering. Strukturnya sangat kuat, tahan cuaca dan tidak mudah aus dengan bentuk bulat mengkilap.

Sebagai material baru, PS Ball memiliki keunggulan sifat-sifat fisik dan kimia yang memberikan kemampuan untuk berbagai penerapan yang luas, seperti pelapis genting metal, manholes, amplas, pemadatan jalan, bahan pemberat, peredam suara dan pelindung radiasi, campuran semen, bahan lantai, pemadat tanah, tiang pancang, pengolahan air dan air buangan, bahan filter, bahan lantai yang tidak licin, bata dan bahan beton prefabrikasi, ubin yang tidak mudah aus, campuran aspal, dan lain-lain.

PS Ball sebagai produk akhir sangat seragam (koefisien keseragaman: 1,22 dibandingkan dengan pasir: 1,64) dengan kekuatan tekan yang lebih besar (161 \% lebih tinggi dari pasir), tingkat kekerasan 740 Vickers (62 Rockwell). PS Ball dapat digunakan sebagai pengganti garnet atau copper slag dan terkadang sebagai pengganti steel ball / steel shot. Dengan tingkat keseragaman tersebut dan kekuatan tekan yang kuat maka material PS Ball dapat digunakan dalam aplikasi teknik sipil. Dalam hal ini digunakan sebagai bahan pengisi atau sebagai bahan pengganti pasir dalam campuran beton untuk mendapatkan kuat tekan yang tinggi.

Beberapa keuntungan lainnya dalam penggunaan PS Ball:

1. PS Ball adalah jenis produk yang ramah lingkungan, aman dan bebas dari silika beracun atau kristal.

2. Rendah debu.

3. Produktivitas tinggi.

PS Ball sangat cepat memotong ke permukaan karena karakter bahan baku, kecepatan, kekerasan (7,5 Mohs) dan bentuk yang berdampak pada permukaan.

4. Konsumsi rendah.

SSPC SP $-6 /$ Sa $2 \quad: 18 \mathrm{Kg} / \mathrm{m}^{2}$

SSPC SP - 10 / Sa $2,5: 32 \mathrm{Kg} / \mathrm{m}^{2}$

SSPC SP $-5 /$ Sa $3 \quad: 52 \mathrm{Kg} / \mathrm{m}^{2}$

5. Daur ulang.

PS Ball dapat digunakan 2 sampai 3 kali.

\section{A. Diversifikasi Aplikasi PS Ball}

PS Ball banyak sekali kegunaannya, antara lain:

1. Abrasive Blasting Material 
PS Ball dapat digunakan sebagai pengganti Terak Garnet atau Tembaga dan terkadang dapat digunakan sebagai pengganti untuk Steel Ball.

\section{Weight Material}

PS Ball lebih berat daripada pasir, oleh karena itu dapat digunakan sebagai bahan pencampuran dalam pertimbangan.

3. Casting Sand.

PS Ball dapat digunakan sebagai Casting Sand untuk pengecoran logam nonferrous, dengan sifat khusus seperti kekerasan, bentuk bulat, ukuran seragam dan efek permeabel.

4. Pengolahan Air.

Dengan bentuk yang seragam, PS Ball dapat digunakan sebagai media filtrasi untuk daur ulang pengolahan air limbah industri. Telah terbukti memiliki efisiensi lebih tinggi daripada pasir sungai untuk menghilangkan polusi.

5. Roofing Granules.

PS Ball dapat digunakan secara luas sebagai butiran tahan tinggi untuk menghasilkan atap aspal herpes zoster. Hal ini telah dibuktikan bahwa penampilan dan masa manfaat dari herpes zoster diterapkan dengan PS Ball lebih baik dari batu hancur.

6. Bahan non-slip.

PS Ball memiliki koefisien tinggi akan gesekan dan tahan lama untuk slip. Dengan penerapannya untuk menutupi jalan, non-slip efek dapat dicapai sangat dengan daya tahan abrasi.

7. Penguatan Bahan.

Karena properti khusus koherensi dengan aspal atau beton, dan daya tahan abrasi, $P S$ Ball dapat digunakan sebagai Bahan Perbaikan atau Penguatan dengan efisiensi tinggi.

8. Poly-concrete Material.

PS Ball dapat digunakan sebagai salah satu bahan utama untuk produksi Polyconcrete beton. Penggunaan properti semen-ramah, penyerapan air rendah dan kekerasan, baik Poly-con produk dapat dibuat dengan penghematan biaya.

9. Sand-pile Material.

Untuk pengerasan tanah dari tepi pantai atau tepi sungai, biasanya pasir telah diterapkan untuk memompa air. Penggunaan PS Ball, dapat dilakukan dengan efisiensi tinggi karena kekerasan properti PS Ball memiliki bentuk seragam.

10. Road Pavement Material.

Pengaruh Penggunaan PS Ball Sebagai Pengganti Pasir Terhadap Kuat Tekan Beton (Ronald Simatupang, Naning Diyah Ulfaturosida) 
a. Untuk Jalan Beton.

Campuran beton menggunakan PS Ball dapat mengurangi biaya semen dan campuran kimia. Selain itu, daya tahan akan sangat meningkat.

b. Untuk Jalan Aspal.

Warna hitam jalan bisa bertahan lebih lama menggunakan PS ball dari jalan konvensional, dan daya tahan akan meningkat sangat.

\section{Permeabel Reaktive Material.}

Memanfaatkan sifat kekerasan, bentuk seragam dan bola, PS Ball dapat digunakan sebagai Bahan Reaktif Permeable dalam limbah ( makanan atau sampah) daerah pembuangan.

\section{METODOLOGI}

\section{Pemeriksaan Agregat Halus}

Pemeriksaan agregat diperlukan untuk mendapatkan bahan campuran beton yang memenuhi spesifikasi material, dalam hal ini sesuai dengan SNI dan ASTM. Selain itu, pengujian material juga untuk menganalisis sifat dan karakteristik beton yang dibuat sesuai dengan kinerja tertentu yang diharapkan baik pada saat beton segar ataupun beton yang telah mengeras. Adapun pemeriksaan agregat yang dilakukan adalah sebagai berikut:

\section{Pengujian Kadar Air}

Dalam campuran beton kadar air agregat dapat mempengaruhi banyaknya air yang dibutuhkan karena jika agregatnya tidak jenuh air, maka agregat akan menyerap air campuran beton. Sebaliknya air bebas pada permukaan agregat akan menjadi bagian air dari campuran beton.

Karena itu dalam perhitungan, keadaan jenuh kering permukaan SSD (Saturated Surface Dry) dipakai sebagai dasar campuran beton. Dengan mengetahui kadar air dari agregat, dapat ditaksir penambahan air dalam suatu adukan. Salah satu cara untuk menentukan kadar air ialah dengan mencari kehilangan berat pada agregat akibat pemanasan. Pada pengujian ini diperoleh kadar air agregat halus adalah 1,75 \%.

\section{Pengujian Berat Jenis (specific gravity) dan Absorpsi}

Pengujian specific gravity dan absorpsi adalah untuk mengetahui perbandingan antara berat kering jenuh permukaan agregat halus SSD (Saturated Surface Dry) dengan berat air suling yang volumenya sama dengan volume agregat halus dalam keadaan jenuh 
pada temperatur tertentu. Selain itu juga, untuk mengetahui persentase berat air yang dapat diserap pori-pori agregat halus sampai dicapai keadaan jenuh kering permukaan. Jika nilai absorpsinya lebih kecil dari nilai kadar air, ini berarti agregat halus dalam keadaan kelebihan air. Menurut ASTM C 127 - 84 dan ASTM C 128 - 84, nilai specific gravity untuk agregat halus harus berada antara 2,4 - 2,9. Hasil pemeriksaan analisis spesific gravity dan absorpsi untuk agregat halus dapat dilihat pada Tabel 3.

Tabel 3. Specific Gravity (Berat Jenis) dan Absorpsi Kondisi SSD.

\begin{tabular}{|l|c|}
\hline \multicolumn{1}{|c|}{ sampel } & Agregat Halus \\
\hline A. Berat Piknometer (gr) & 348 \\
\hline B. Berat Contoh $S S D$ (gr) & 590 \\
\hline C Berat Piknometer + air (gr) & 1290 \\
\hline D. Berat piknometer + contoh $S S D+$ air (gr) & 1638 \\
\hline E. Berat contoh $S S D$ kering (gr) & 565 \\
\hline Apparent $S . G\{$ E/[E-(D-C)]\} & 2,60 \\
\hline Bulk $S . G$ kondisi kering $\{$ E/[B-(D-C)]\} & 2,33 \\
\hline Bulk $S . G$ kondisi $S S D\{$ B/[B-(D-C)]\} & 2,40 \\
\hline Persentase Absorpsi air [(B-E)/E] X $100 \%$ & $4,43 \%$ \\
\hline
\end{tabular}

\section{Pengujian Analisis Saringan}

Pengujian gradasi dan modulus kehalusan butir adalah untuk mengetahui susunan besar butir agregat halus dan menghitung nilai modulus halus butir. Tingkat gradasi agregat halus sangat penting karena campuran pasir, semen, dan air berfungsi sebagai pelumas pada campuran beton sehingga menentukan kemudahan pengerjaan (workability) dan sifat kohesi dari campuran beton.

Menurut ASTM C 33 batas nilai modulus kehalusan butir adalah antara 2,3 - 3,1. Jika nilai MHB kurang dari 2,3 berarti agregat tersebut terlalu halus dan harus diperbaiki dengan menambahkan agregat yang lebih kasar. Demikian juga jika nilai MHB lebih dari 3,2 berarti agregat tersebut terlalu kasar dan harus diperbaiki dengan menambahkan agregat yang lebih halus.

Pada pengujian ini diperoleh gradasi agregat halus masuk dalam daerah 2 dengan nilai modulus halus butir 2,5601. Hasil pengujian analisa saringan dan modulus halus butir untuk agregat halus dapat dilihat pada Tabel 4 dan Gambar 4. 
Tabel 4. Analisis Saringan Agregat Halus.

\begin{tabular}{|c|c|c|c|c|}
\hline \multirow[t]{2}{*}{ Ukuran Saringan } & $\begin{array}{c}\text { Berat } \\
\text { Tertahan }\end{array}$ & $\begin{array}{c}\text { Berat } \\
\text { Tertahan }\end{array}$ & $\begin{array}{c}\text { Berat } \\
\text { Tertahan } \\
\text { Kumulatif }\end{array}$ & $\begin{array}{c}\text { Berat Lolos } \\
\text { Kumulatif }\end{array}$ \\
\hline & (gr) & $(\%)$ & (\%) & (\%) \\
\hline $4,76 \mathrm{~mm}$ & 15,6 & 1,56 & 1,56 & 98,44 \\
\hline $\begin{array}{ll}\text { No.8 } & 2,40 \mathrm{~mm}\end{array}$ & 61,1 & 6,11 & 7,67 & 92,33 \\
\hline No.16 $1,20 \mathrm{~mm}$ & 186,4 & 18,64 & 26,31 & 73,69 \\
\hline No.30 $0,60 \mathrm{~mm}$ & 260 & 26,00 & 52,31 & 47,69 \\
\hline $\begin{array}{ll}\text { No.50 } & 0,30 \mathrm{~mm}\end{array}$ & 231,4 & 23,14 & 75,45 & 24,55 \\
\hline No.100 $0,15 \mathrm{~mm}$ & 172,6 & 17,26 & 92,71 & 7,29 \\
\hline Pan $<0,15 \mathrm{~mm}$ & 72,9 & 7,29 & - & - \\
\hline jumlah & 1000 & 100,00 & 256,01 & - \\
\hline
\end{tabular}

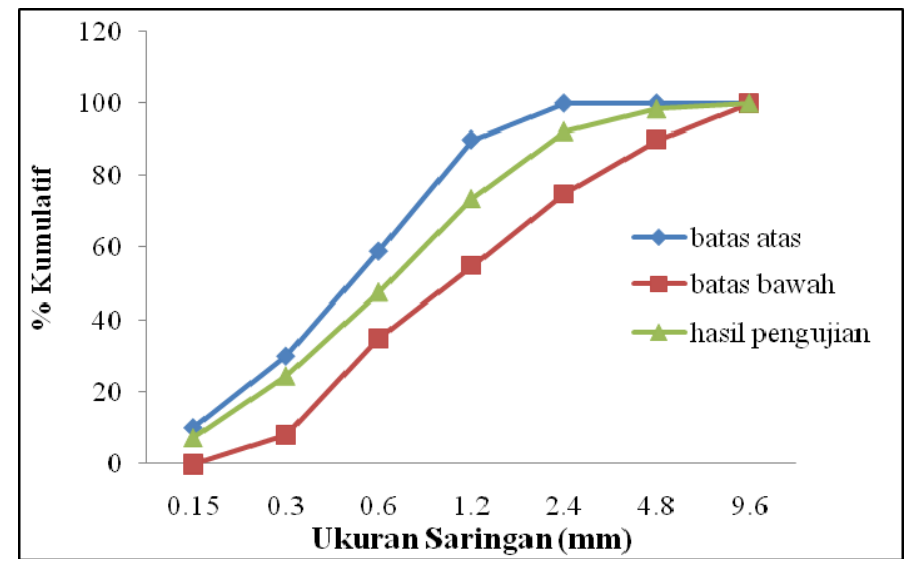

Gambar 4. Batas Gradasi Agregat Halus dalam Daerah Gradasi 2.

(Sumber: Grafik 4. SNI SNI 03-2834-2000)

\section{Pengujian Agregat Kasar}

Pengujian agregat diperlukan untuk mendapatkan bahan campuran beton yang memenuhi spesifikasi material, dalam hal ini sesuai dengan SNI dan ASTM. Selain itu, pengujian material juga untuk menganalisis sifat dan karakteristik beton yang dibuat sesuai dengan kinerja tertentu yang diharapkan baik pada saat beton segar ataupun beton yang telah mengeras. Adapun pengujian agregat yang dilakukan adalah sebagai berikut: 


\section{Pengujian Kadar Air}

Dalam campuran beton kadar air agregat dapat mempengaruhi banyaknya air yang dibutuhkan karena jika agregatnya tidak jenuh air, maka agregat akan menyerap air campuran beton. Sebaliknya air bebas pada permukaan agregat akan menjadi bagian air dari campuran beton. Karena itu dalam perhitungan, keadaan jenuh kering permukaan SSD (Saturated Surface Dry) dipakai sebagai dasar campuran beton. Dengan mengetahui kadar air dari agregat, dapat ditaksir penambahan air dalam suatu adukan. Salah satu cara untuk menentukan kadar air ialah dengan mencari kehilangan berat pada agregat akibat pemanasan. Pada pengujian ini diperoleh kadar air agregat kasar adalah 3,63 \%.

\section{Pengujian Berat Jenis (specific gravity) dan Absorpsi}

Pengujian specific gravity dan absorpsi adalah untuk mengetahui perbandingan antara berat kering jenuh permukaan agregat kasar SSD (Saturated Surface Dry) dengan berat air suling yang volumenya sama dengan volume agregat kasar dalam keadaan jenuh pada temperatur tertentu. Selain itu juga, untuk mengetahui persentase berat air yang dapat diserap pori-pori agregat kasar sampai dicapai keadaan jenuh kering permukaan. Jika nilai absorpsinya lebih kecil dari nilai kadar air, ini berarti agregat kasar dalam keadaan kelebihan air. Menurut ASTM C 127 - 84 dan ASTM C 128 - 84, nilai specific gravity untuk agregat kasar harus berada antara 2,4 - 2,9. Hasil pengujian analisis spesific gravity dan absorpsi untuk agregat kasar dapat dilihat pada Tabel 5.

Tabel 5. Specific Gravity (Berat Jenis) dan Absorpsi Kondisi SSD.

\begin{tabular}{|l|c|}
\hline \multicolumn{1}{|c|}{ nama } & Agregat Kasar \\
\hline A. Berat Piknometer (gr) & 348 \\
\hline B. Berat Contoh $S S D$ (gr) & 600 \\
\hline C Berat Piknometer + air (gr) & 1467 \\
\hline D. Berat piknometer + contoh $S S D+$ air (gr) & 1815 \\
\hline E. Berat contoh $S S D$ kering (gr) & 570 \\
\hline Apparent $S . G\{$ E/[E-(D-C)]\} & 2,56 \\
\hline Bulk $S . G$ kondisi kering $\{$ E/[B-(D-C)]\} & 2,26 \\
\hline Bulk $S . G$ kondisi $S S D$ [B/[B-(D-C)]\} & 2,38 \\
\hline Persentase Absorpsi air [(B-E)/E] X $100 \%$ & $5,26 \%$ \\
\hline
\end{tabular}

Pengaruh Penggunaan PS Ball Sebagai Pengganti Pasir Terhadap Kuat Tekan Beton (Ronald Simatupang, Naning Diyah Ulfaturosida) 


\section{Pengujian Analisis Saringan}

Pengujian gradasi dan modulus kehalusan butir adalah untuk mengetahui susunan besar butir agregat kasar dan menghitung nilai modulus kasar butir. Tingkat gradasi agregat kasar sangat penting karena campuran pasir, kerikil, semen, dan air berfungsi sebagai pelumas pada campuran beton sehingga menentukan kemudahan pengerjaan (workability) dan sifat kohesi dari campuran beton.

Pada pengujian ini diperoleh gradasi agregat kasar dengan nilai modulus halus kasar 7,393. Hasil pengujian analisa saringan, dan modulus kasar butir untuk agregat kasar dapat dilihat pada Tabel 6 dan Gambar 5.

Tabel 6. Analisis Saringan Agregat kasar.

\begin{tabular}{|l|c|c|c|c|}
\hline \multirow{2}{*}{$\begin{array}{c}\text { Ukuran } \\
\text { Saringan }\end{array}$} & $\begin{array}{c}\text { Berat } \\
\text { Tertahan }\end{array}$ & $\begin{array}{c}\text { Berat } \\
\text { Tertahan }\end{array}$ & $\begin{array}{c}\text { Berat Tertahan } \\
\text { Kumulatif }\end{array}$ & $\begin{array}{c}\text { Berat Lolos } \\
\text { Kumulatif }\end{array}$ \\
\cline { 2 - 5 } & $\mathbf{( g r )}$ & $\mathbf{( \% )}$ & $\mathbf{( \% )}$ & $\mathbf{( \% )}$ \\
\hline $37,5 \mathrm{~mm}$ & - & - & - & 100 \\
\hline $25,4 \mathrm{~mm}$ & - & - & - & 100 \\
\hline $12,7 \mathrm{~mm}$ & 2000 & 50 & 50 & 50 \\
\hline $9,5 \mathrm{~mm}$ & 1573,67 & 39,34 & 89,34 & 10,66 \\
\hline $4,75 \mathrm{~mm}$ & 426,33 & 10,66 & 100 & 0 \\
\hline $2,36 \mathrm{~mm}$ & 0 & 0 & 100 & 0 \\
\hline $1,18 \mathrm{~mm}$ & 0 & 0 & 100 & 0 \\
\hline $0,60 \mathrm{~mm}$ & 0 & 0 & 100 & 0 \\
\hline $0,3 \mathrm{~mm}$ & 0 & 0 & 100 & - \\
\hline $0,15 \mathrm{~mm}$ & 0 & 0 & 100 & 0 \\
\hline PAN & - & - & - & 739,34 \\
\hline Jumlah & 4000 & 100 & & 0 \\
\hline
\end{tabular}




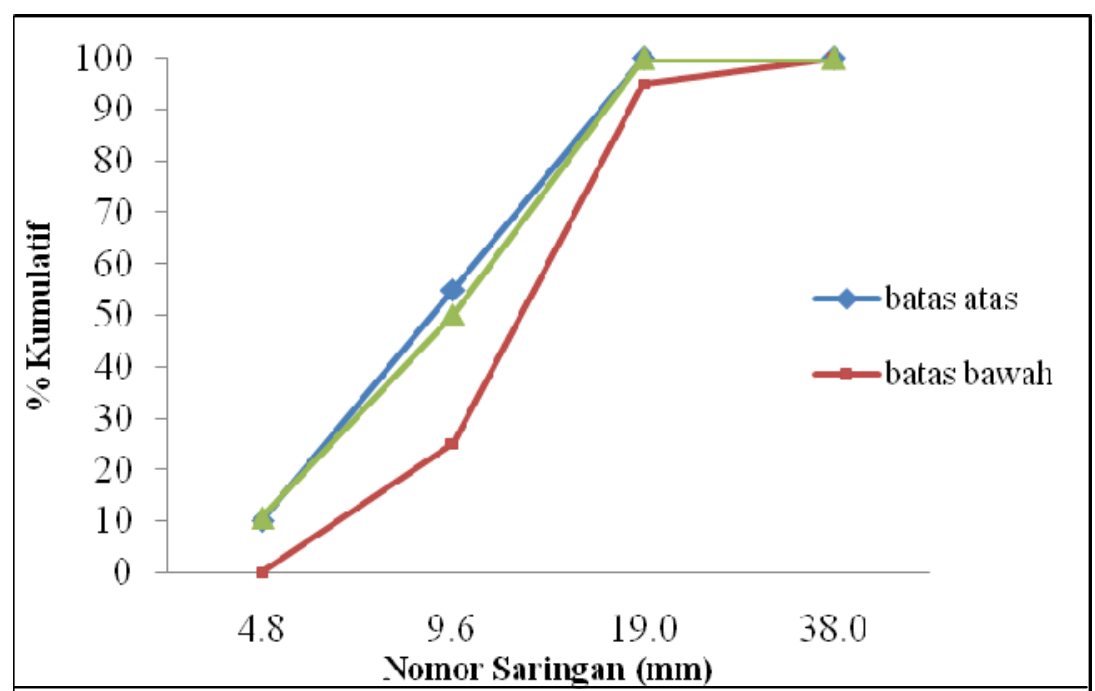

Gambar 5. Batas Gradasi Agregat Kasar dalam Daerah Gradasi

Ukuran 20 mm. (Sumber: Grafik 8. SNI SNI 03-2834-2000)

\section{Benda Uji}

Benda uji yang digunakan adalah silinder dengan diameter $150 \mathrm{~mm}$ dan tinggi 300 mm. Gambar silinder dan cetakan benda uji dapat dilihat pada Gambar 6 .

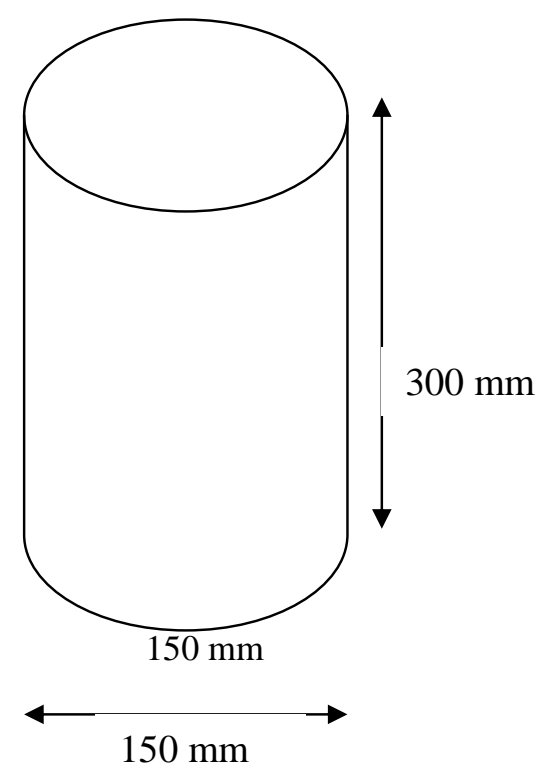

Gambar 6. Benda Uji Silinder. 


\section{ANALISIS}

Pengujian benda uji dilakukan pada umur beton 3 hari, 7 hari, 14 hari, 21 hari dan 28 hari untuk beton normal dan beton dengan menggunakan PS Ball. Berdasarkan hasil pengujian untuk beton normal didapatkan beton pada umur 28 hari sebesar 25,65 MPa dan sudah memenuhi target yang diinginkan yaitu sebesar $25 \mathrm{MPa}$, sehingga mix design dapat digunakan dalam campuran dengan menggunakan PS Ball sebagai bahan pengganti pasir sesuai dengan kadar yang telah ditentukan. Hasil pengujian beton normal dengan benda uji silinder dapat dilihat pada Gambar 7 dan Tabel 7.

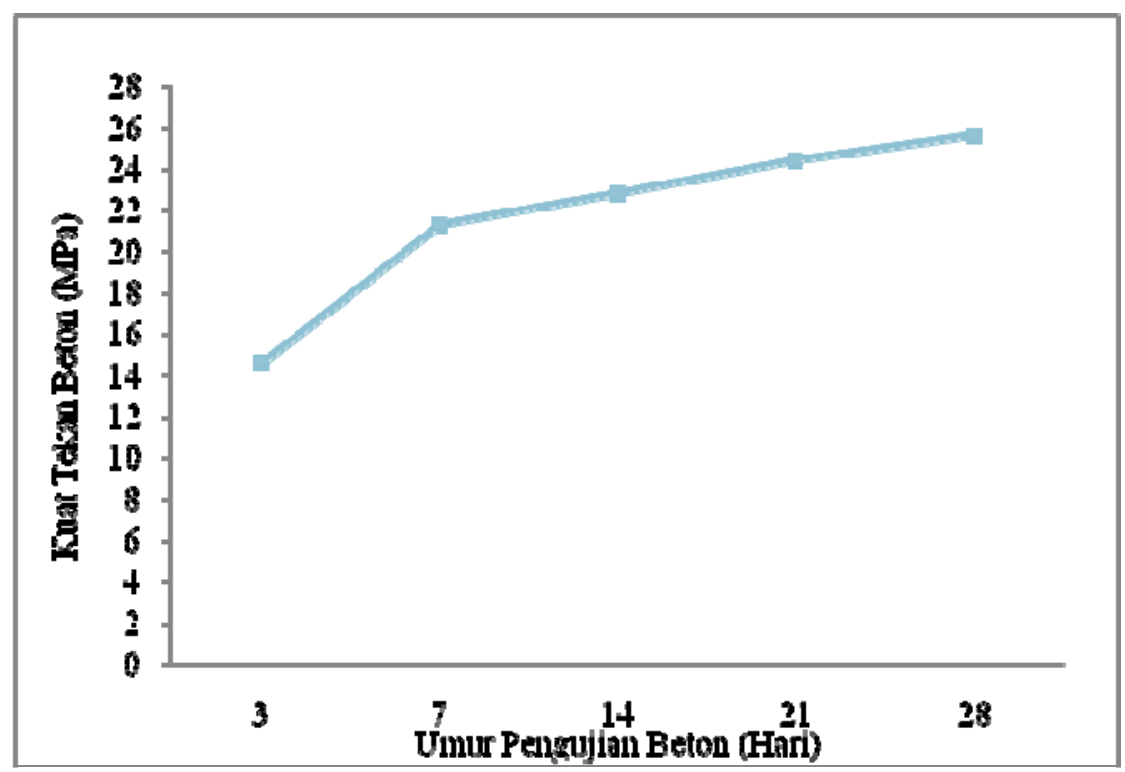

Gambar 7. Pengujian kuat Tekan Beton Normal.

Tabel 7. Kuat Tekan Rencana Beton Normal.

\begin{tabular}{|l|l|l|l|l|l|}
\hline Beton normal kuat $\begin{array}{l}\text { Umur Rencana } \\
\text { tekan rencana 25 } \\
\text { MPa }\end{array}$ & 3 hari & 7 hari & 14 hari & 21 hari & 28 hari \\
\cline { 2 - 6 } & 14,62 & 21,31 & 22,82 & 24,42 & 25,65 \\
\hline
\end{tabular}

Dari hasil pengujian yang telah dilakukan dapat dilihat peningkatan kuat tekan beton dengan menggunakan PS Ball sebagai bahan pengganti pasir. Pada pengujian beton umur 3 hari dapat dilihat peningkatan kuat tekan yang dihasilkan. Peningkatan maksimum kuat tekan yang dihasilkan yaitu pada saat mengganti pasir dengan 5 \% PS 
Ball ke dalam campuran beton. Kuat tekan yang dihasilkan sebesar 20,37 MPa dan dapat dilihat pada Gambar 8.

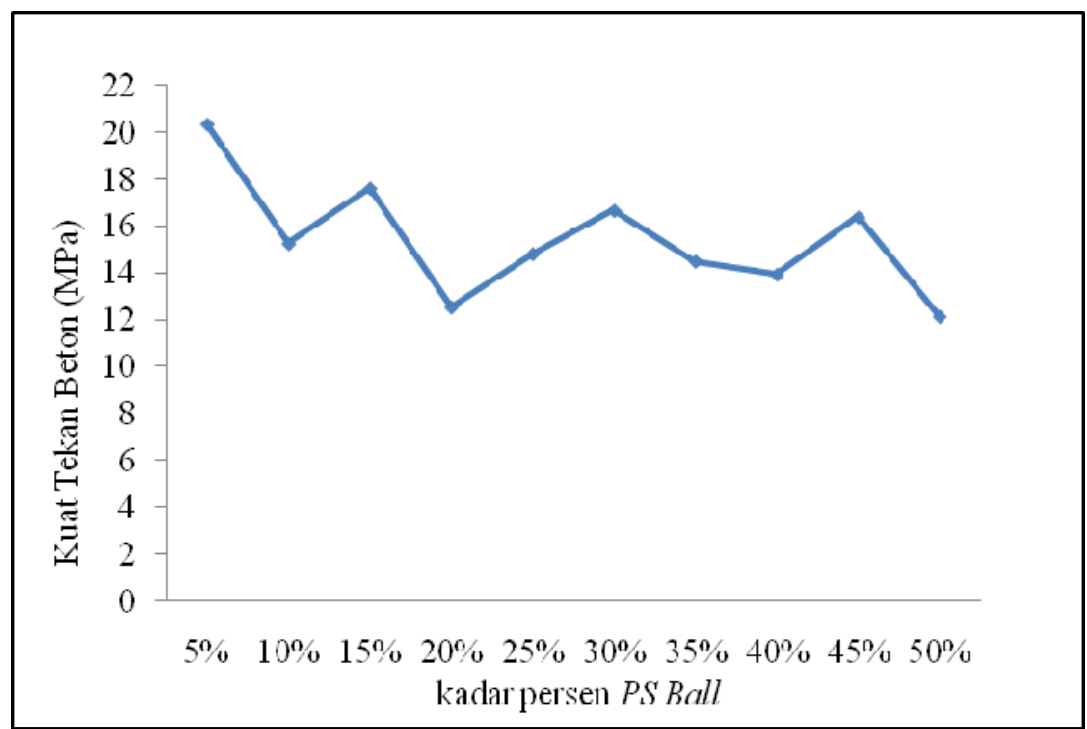

\section{Gambar 8. Pengujian kuat Tekan Beton Dengan Menggunakan PS Ball Sebagai Pengganti Pasir Pada umur 3 Hari.}

Pada pengujian beton umur 7 hari dapat dilihat peningkatan kuat tekan yang dihasilkan. Peningkatan maksimum kuat tekan yang dihasilkan dapat di lihat pada Gambar 9.

Dari hasil pengujian yang telah dilakukan dapat dilihat peningkatan kuat tekan beton dengan menggunakan PS Ball sebagai bahan pengganti pasir. Pada pengujian beton umur 14 hari dapat dilihat peningkatan kuat tekan yang dihasilkan. Peningkatan maksimum kuat tekan yang dihasilkan yaitu pada saat mengganti pasir dengan 5 \% PS Ball ke dalam campuran beton. Kuat tekan yang dihasilkan sebesar 26,50 MPa. Nilai Kuat tekan umur 14 hari dapat di lihat pada Gambar 10. 


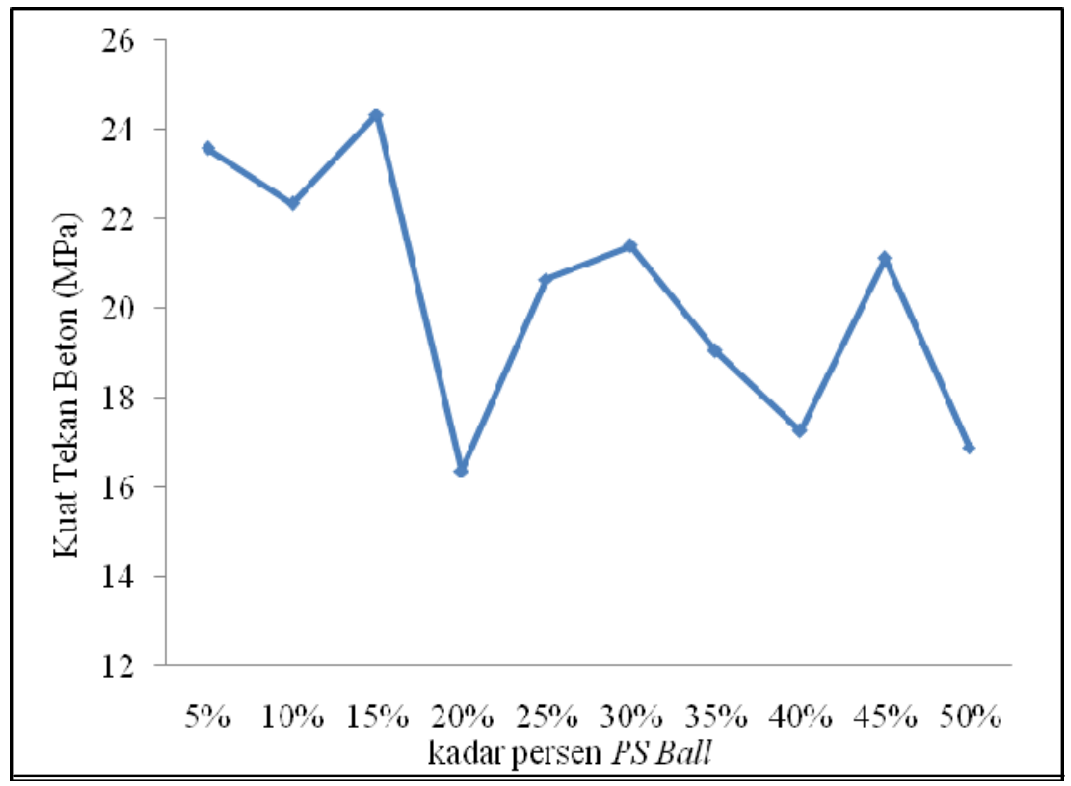

Gambar 9. Pengujian kuat Tekan Beton Dengan Menggunakan PS Ball Sebagai

Pengganti Pasir Pada umur 7 Hari.

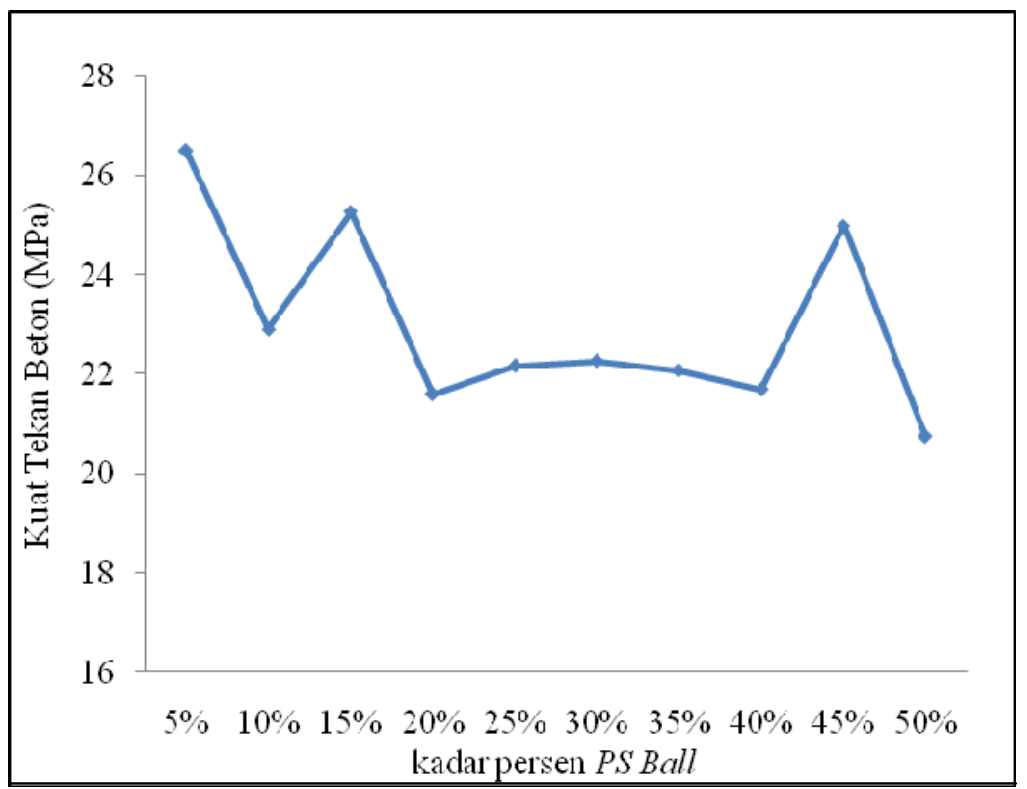

Gambar 10. Pengujian kuat Tekan Beton Dengan Menggunakan PS Ball Sebagai Pengganti Pasir Pada umur 14 Hari.

Peningkatan maksimum kuat tekan yang dihasilkan yaitu pada saat mengganti pasir dengan 5 \% PS Ball ke dalam campuran beton. Kuat tekan yang dihasilkan sebesar 28,36 MPa. Dibandingkan dengan kuat tekan beton pada saat umur 14 hari, kuat tekan beton pada umur 21 hari mengalami peningkatan dan dapat dilihat pada Gambar 11. 


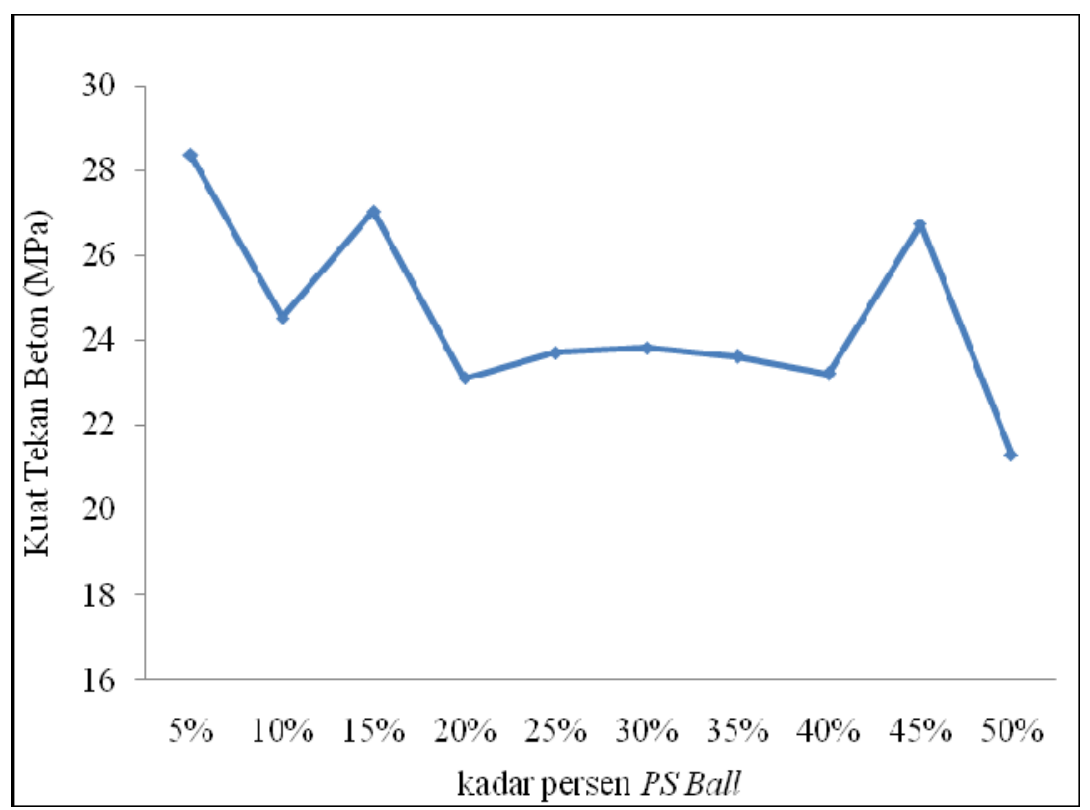

\section{Gambar 11. Pengujian kuat Tekan Beton Dengan Menggunakan PS Ball Sebagai Pengganti pasir Pada umur 21 Hari.}

Pada pengujian beton umur 28 hari dapat dilihat peningkatan kuat tekan yang dihasilkan. Peningkatan maksimum kuat tekan yang dihasilkan yaitu pada saat mengganti pasir dengan 35 \% PS Ball ke dalam campuran beton. Kuat tekan yang dihasilkan sebesar 29,80 MPa. Dibandingkan dengan kuat tekan umur 3 hari, 7 hari, 14 hari, dan 21 hari, pada kuat tekan umur 28 hari mengalami perbedaan. Kuat tekan maksimum bukan pada saat mengganti pasir dengan PS Ball dengan kadar $5 \%$ melainkan dengan kadar yang jauh berbeda yaitu pada saat menggunakan PS Ball dengan kadar 35 \% sebagai pengganti pasir. Hal ini dapat dilihat pada Gambar 12. 


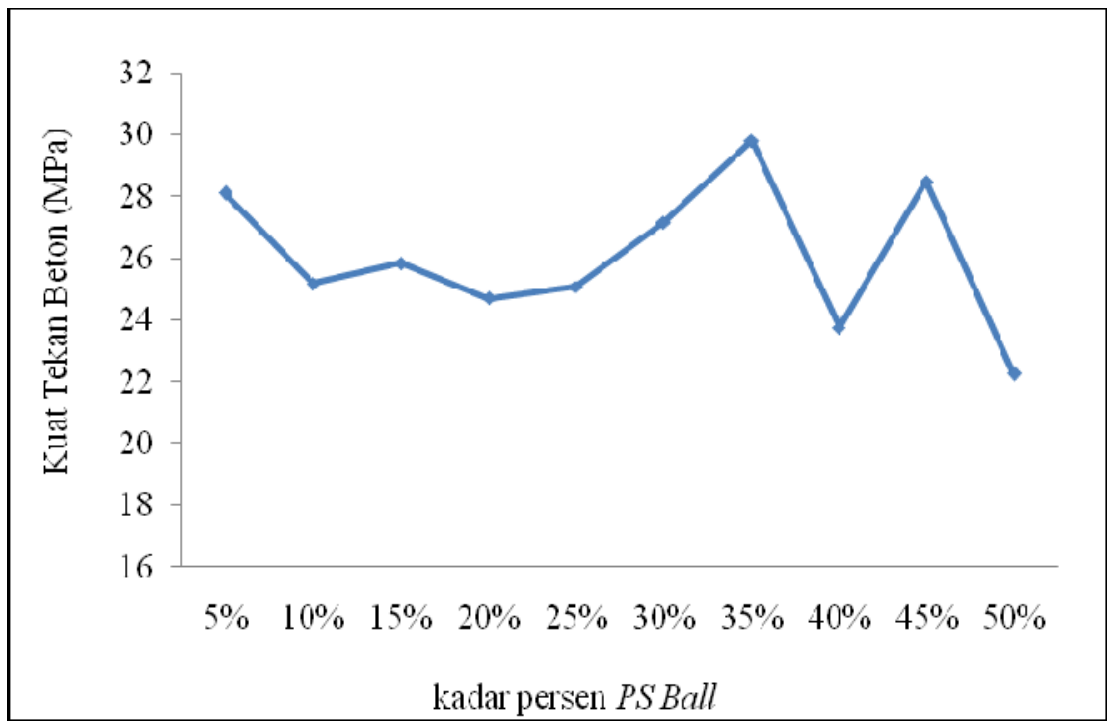

\section{Gambar 12. Pengujian kuat Tekan Beton Dengan Menggunakan PS Ball Sebagai Pengganti Pasir Pada umur 28 Hari.}

Berdasarkan Gambar 13 dapat dilihat peningkatan kuat tekan beton dengan menggunakan PS Ball sebagai bahan pengganti pasir, peningkatan maksimum terjadi pada kadar PS Ball 35 \%. Pada kadar 5 \% dan 45 \% terjadi peningkatan kuat tekan tetapi tidak sampai melebihi saat kadar 35 \%. Pada kadar PS Ball 20 \% terjadi penurunan kuat tekan yang signifikan. Dengan kadar PS Ball 50 \% beton sudah mengalami penurunan kuat tekan jauh dibandingkan dengan kadar PS Ball yang lainnya. Kuat tekan maksimum pada saat umur 3 hari, 7 hari, 14 hari, dan 21 hari yaitu pada saat mengganti pasir dengan PS Ball sebanyak $5 \%$, sedangkan pada saat umur 28 hari kuat tekan maksimal terjadi pada saat mengganti pasir dengan PS Ball sebayak $35 \%$. 


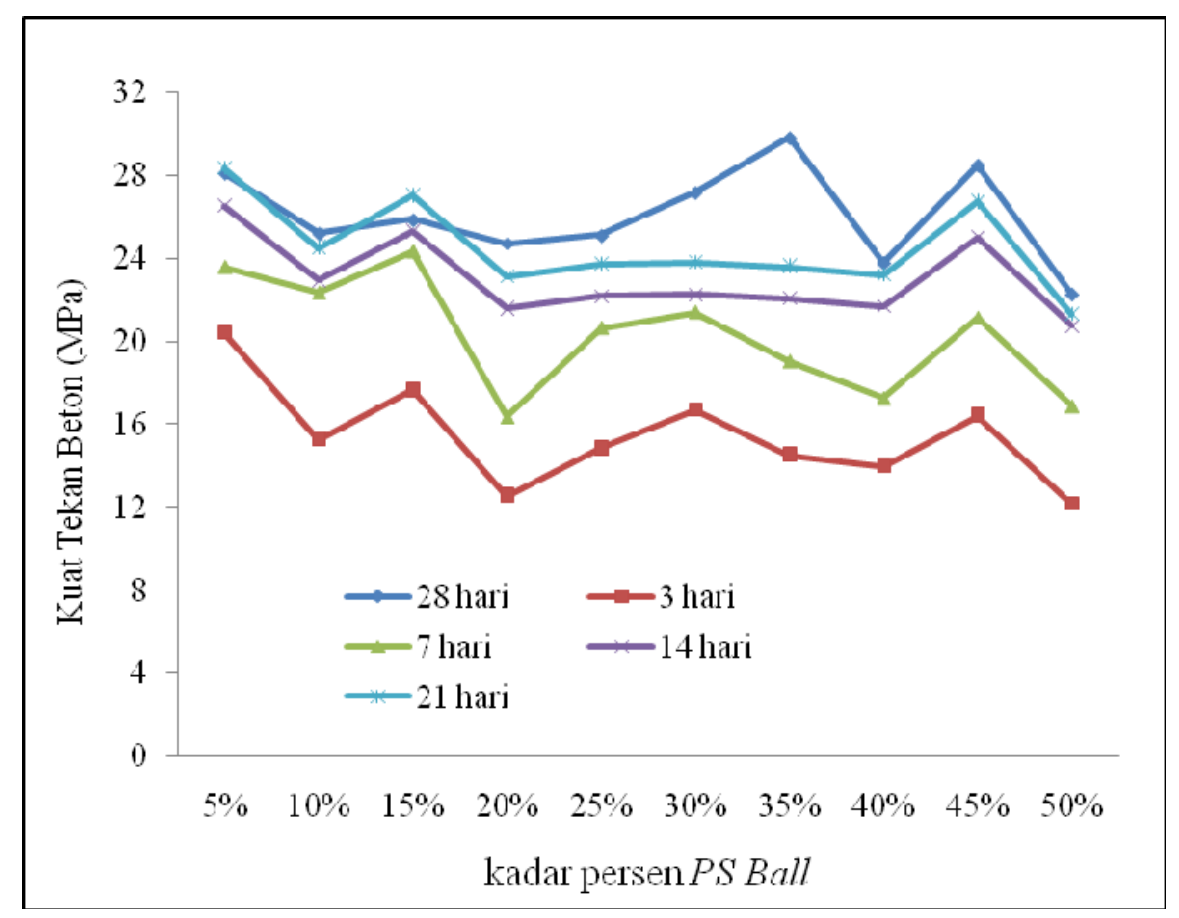

\section{Gambar 13. Perbandingan Kuat tekan Beton dengan Menggunakan PS Ball Sebagai Bahan Pengganti Pasir.}

Pada Tabel 8 dapat dilihat peningkatan kuat tekan beton pada umur 28 hari beton dengan menggunakan PS Ball sebagai pengganti pasir.

Tabel 8. Peningkatan Kuat Tekan Beton Sesuai Umur Beton (MPa).

\begin{tabular}{|l|l|l|l|l|l|l|l|l|l|l|}
\hline $\begin{array}{l}\text { umur } \\
\text { beton } \\
\text { (hari) }\end{array}$ & $5 \%$ & $10 \%$ & $15 \%$ & $20 \%$ & $25 \%$ & $30 \%$ & $35 \%$ & $40 \%$ & $45 \%$ & $50 \%$ \\
\hline 3 & 20,37 & 15,28 & 17,64 & 12,56 & 14,85 & 16,69 & 14,52 & 13,96 & 16,41 & 12,17 \\
\hline 7 & 23,58 & 22,35 & 24,33 & 16,37 & 20,65 & 21,41 & 19,05 & 17,26 & 21,13 & 16,88 \\
\hline 14 & 26,50 & 22,92 & 25,28 & 21,60 & 22,16 & 22,26 & 22,07 & 21,69 & 24,99 & 20,75 \\
\hline 21 & 28,36 & 24,52 & 27,05 & 23,11 & 23,72 & 23,82 & 23,61 & 23,21 & 26,74 & 21,31 \\
\hline 28 & 28,11 & 25,18 & 25,84 & 24,71 & 25,09 & 27,16 & 29,80 & 23,77 & 28,48 & 22,26 \\
\hline
\end{tabular}

Pada Tabel 9 dapat terlihat peningkatan kuat tekan beton umur 28 hari dibandingkan dengan beton normal yang didesain. Dan dapat terlihat bahwa peningkatan 
kuat tekan beton optimum tercapai pada saat pasir digantikan dengan PS Ball sebanyak $35 \%$. Peningkatan yang terjadi sebanyak 1,16 kali dari kuat tekan beton normal yang diuji.

Tabel 9. Perbandingan Kuat Tekan Dengan Beton Normal.

\begin{tabular}{|c|c|c|c|}
\hline No & Keterangan & $\begin{array}{c}\text { Kuat Tekan } \\
(\mathrm{MPa})\end{array}$ & $\begin{array}{c}\text { Perbandingan kuat tekan } \\
\text { dengan beton normal }\end{array}$ \\
\hline 1 & beton normal & 25,65 & - \\
\hline 2 & $5 \%$ & 28,11 & 0,98 \\
\hline 3 & $10 \%$ & 25,18 & 1,01 \\
\hline 4 & $15 \%$ & 25,84 & 0,96 \\
\hline 5 & $20 \%$ & 24,71 & 0,98 \\
\hline 6 & $25 \%$ & 25,09 & 1,06 \\
\hline 7 & $30 \%$ & 27,16 & 1,16 \\
\hline 8 & $35 \%$ & 29,80 & 0,93 \\
\hline 9 & $40 \%$ & 23,77 & 1,11 \\
\hline 10 & $45 \%$ & 28,48 & 0,87 \\
\hline 11 & $50 \%$ & 22,26 & \\
\hline
\end{tabular}

\section{SIMPULAN}

Simpulan yang dapat diambil dari dalam penelitian ini yaitu Penggunaan PS Ball dapat digunakan dalam campuran beton sebagai pengganti pasir dalam campuran beton. Hasil pengujian beton dengan menggunakan PS Ball sebagai bahan pengganti pasir dalam campuran beton didapatkan nilai kuat tekan maksimum beton dengan mengganti pasir dengan PS Ball sebanyak 35 \% PS Ball dan kuat tekan minimum beton pada kadar 50 \% PS Ball. Hasil penelitian dengan menggunakan PS Ball sebagai bahan pengganti pasir pada campuran beton, didapatkan peningkatan sebesar 1,16 kali dari kuat tekan beton normal yang telah diuji pada kadar $35 \%$.

\section{DAFTAR PUSTAKA}

1. ACI 318-02, "Building Codes Requirment for Structural Concrete and Commentary", ACI Committee, 2002.

2. Annual book of ASTM Standart, Destignation C 22, "Test Method for Bulk Density (Unit Weight)". 
3. Annual book of ASTM Standart, Destignation C 33 / 33 M, "Standart Specification for Concrete Aggregate”.

4. Annual Book of ASTM Standart, Destignation C 39a - 93, "Standart Specification for Concrete Agregat".

5. Annual book of ASTM Standart, Destignation C 40, "Test Method for Organic Impurities In Fine Aggregates for Concrete".

6. Annual Book of ASTM Standart, Destignation C 78 - 94, "Standart Practice for Making and Curing Concrete Test Specimen in Laboratory".

7. Annual book of ASTM Standart, Destignation C 136, "Test Method for Sieve Analysis of Fine and Coarse Aggregates".

8. Annual book of ASTM Standart, Destignation C 143, "Standart Test Method For Slump of Hydraulic Cement Concrete".

9. Annual book of ASTM Standart, Destignation C 873, “ Standart Test Method For Compressive Strength of Concrete Cylinders Cast In Place In Cylindical Molds".

10. Annual book of ASTM Standart, Destignation C 989, "Spec for Slag Cement For Use In Concrete and Mortars".

11. ASTM A 706 M-93a, "Standard Specification for Low-Alloy Steel Deformed Bars for Concrete Reinforcement", Annual Book of ASTM Standards, Volume 01.04, pp. 353-357.

12. Aulia Hamzah, "Sifat Fisik dan Mekanik Beton Mutu Tinggi dengan Campuran Copper slag”, Tugas Akhir S - 1, FTSP, ITS, 1999.

13. Idris dan Rifai, “Buku Beton”, 2002.

14. http://purnabajaharsco.blogspot.com, diunduh September 2013

15. SNI 03- 2834 - 2000, "Tata Cara Pembuatan Rencana Campuran Beton Normal”, 2000.

16. SNI 03 - 2847 - 2002, "Tata Cara Perhitungan Struktur Beton untuk Bangunan Gedung”, 2002. 